\title{
Analisis Kepuasan Pengguna Terhadap Penerapan Simak Online Menggunakan Metode End User Computing Satisfaction (EUCS) (UIN Raden Fatah Palembang)
}

\author{
Yeni Erlika ${ }^{1}$, Freddy Kurnia Wijaya ${ }^{2}$, Rusmala Santi ${ }^{3}$ \\ yeenierlika@gmail.com ${ }^{1}$, freddykurniawijaya_uin@radenfatah.ac.id ${ }^{2}$, \\ rusmalasanti_uin@radenfatah.ac.id ${ }^{3}$ \\ ${ }^{1}$ Prodi Sistem Informasi, Fakultas Sains dan Teknologi, UIN Raden Fatah Palembang \\ ${ }^{2}$ Prodi Sistem Informasi, Fakultas Sains dan Teknologi, UIN Raden Fatah Palembang \\ ${ }^{3}$ Prodi Sistem Informasi, Fakultas Sains dan Teknologi, UIN Raden Fatah Palembang
}

Diterima: 4 Mei 2017 |Direvisi: 25 Mei 2017 | Disetujui: 9 Juni 2017

(C) 2017 Program Studi Sistem Informasi Fakultas Sains dan Teknologi, Universitas Islam Negeri Raden Fatah Palembang, Indonesia

\begin{abstract}
Abstrak: Penggunaan simak online perlu dilakukan review untuk mengukur tingkat kepuasan pengguna. Penelitian ini bertujuan untuk mengetahui tingkat kepuasan pengguna simak online dengan menggunakan pendekatan model kepuasan pengguna akhir komputer EUCS yang berfokus pada kepuasan pengguna yang mencakup lima dimensi; content, accuracy, format, ease of use, timeliness. Data dalam penelitian ini dikumpulkan dengan menggunakan kuesioner yang disebarkan kepada 390 responden terdiri dari dosen dan mahasiswa/i di Universitas Islam Negeri raden Fatah Palembang. Hasil dari penelitian ini adalah tingkat kepuasan pengguna simak online sebesar $13 \%$ merasa sangat puas, $44 \%$ merasa puas, 34\% merasa cukup puas, 9\% merasa tidak puas, $1 \%$ merasa sangat tidak puas. Hasil penelitian ini sebagai masukan bagi Universitas Islam Negeri Raden Fatah Palembang khususnya untuk simak online dikaitkan dengan lima (5) variabel yang ada masih harus dan terus ditingkatkan lagi. Tingkat kepuasan pengguna akan mempengaruhi kesuksesan dalam penerapan sistem informasi akademik.
\end{abstract}

Kata Kunci: Analisis Kepuasan, Simak Online, EUCS

\begin{abstract}
The use of online checking needs to be done to measure the level of user satisfaction. This study aims to determine the level of user satisfaction refer online by using EUCS computer end user satisfaction model approach that focuses on user satisfaction that includes five dimensions; Content, accuracy, format, ease of use, timeliness. The data in this study were collected by using questionnaires distributed to 390 respondents consisting of lecturers and students at the Islamic University of Raden Fatah Palembang. The result of this research is $13 \%$ satisfaction rate online user satisfaction, $44 \%$ feel satisfied, 34\% feel satisfied, $9 \%$ feel dissatisfied, $1 \%$ feel very dissatisfied. The results of this study as input for the State Islamic University Raden Fatah Palembang, especially to see online is associated with the five variables that exist still have and continue to be improved again. The level of user satisfaction will affect the success in the application of academic information system. Keywords: Satisfaction Analysis, Academic Information System, EUCS
\end{abstract}

\section{PENDAHULUAN}

Era globalisasi, persaingan bisnis menjadi sangat tajam, baik di pasar domestik (Nasional) maupun di pasar internasional/global. Teknologi memberikan nuansa baru dalam perkembangan suatu proses bisnis di dalam sebuah organisasi yang akan menimbulkan persaingan.

Perguruan Tinggi merupakan organisasi yang bergerak di bidang pendidikan, banyak proses bisnis yang harus dilaksanakan dengan baik agar aliran data bisa menjadi informasi yang bermanfaat. Kekhawatiran muncul ketika instansi pendidikan mulai mempunyai proses 
bisnis yang banyak dan besar, karena hal ini akan mempengaruhi keakuratan dan kecepatan data. Universitas Islam Negeri Raden Fatah Palembang saat ini sudah dalam proses menuju pengembangan sistem informasi di semua bidang, salah satunya adalah bidang akademik. Bidang akademik memiliki proses bisnis yang secara terus menerus mengalami perubahan data yang selalu dimanfaatkan saat dibutuhkan. Adanya teknologi informasi membuat manajemen UIN Raden Fatah untuk menggunakan sistem informasi akademik yang mendukung kinerja pegawai, dosen maupun untuk layanan kepada mahasiswa dan mahasiswa, pengelola sistem informasi akademik dituntut memiliki kemampuan merancang dan mengelola sistem informasi akademik dengan baik agar sistem informasi akademik yang dikelola berkelanjutan dan senantiasa digunakan para pengguna, analisis tingkat kepuasan pengguna sistem informasi akademik diharapkan dapat meningkatkan kinerja sistem informasi akademik semaksimal mungkin.

Tingkat kepuasan pelanggan dalam pelayanan merupakan faktor yang penting dalam mengembangkan suatu sistem penyediaan pelayanan yang tanggap dalam kebutuhan pelanggan, meminimalkan biaya dan waktu serta memaksimalkan dampak pelayanan dalam populasi sasaran. Beberapa model telah dibangun untuk menganalisis dan memahami faktorfaktor yang mempengaruhi kepuasan pelanggan salah satunya adalah model End User Computing Satisfaction (EUCS) digunakan untuk mengukur tingkat kepuasan dari pengguna suatu sistem aplikasi dengan membandingkan harapan dan kenyataan dari sebuah sistem informasi. Model ini juga lebih menekankan kepada kepuasan (satisfaction) pengguna akhir terhadap aspek teknologi terdiri dari dimensi isi (content), akurasi (accuracy), bentuk (format), kemudahan (ease of use) dan ketepatan waktu (timeliness) sistem (Doll, W. J., Xia, W., \& Torkzadeh, G., 1994).

\section{METODOLOGI PENELITIAN}

\subsection{Kepuasan pengguna}

Kata kepuasan (satisfaction) berasal dari bahasa latin "satis" (artinya cukup baik, memadai) dan "facio" (melakukan atau membuat). Kepuasan bisa diartikan sebagai upaya pemenuhan sesuatu dan membuat sesuatu memadai. Berdasarkan kajian literatur, datawawancara kelompok, dan wawancara personal. Menurut Giese \& Cote dalam Fandy Tjiptono, kepuasan tidak bisa lepas dari chameleon effects, artinya interpretasi terhadap sebuah definisi sangat bervariasi antar individu dan antar situasi (Tjiptono, F. \& Chandra, G. , 2016). Pengukuran perangkat lunak ini meliputi kuesioner kepuasan pengguna untuk menentukan persepsi dan sikap pengguna mengenai mutu sistem yang mereka gunakan. Perlu diketahui yang harus dipuaskan yaitu pengguna akhir dari sistem (Supranto, 2011).

\subsection{Sistem Informasi Akademik}

Menurut Henry Lucas dalam Yulia Djahir, sistem informasi adalah suatu kegiatan dari prosedur-prosedur yang diorganisasikan, bila mana dieksekusi akan menyediakan informasi untuk mendukung pengambilan keputusan dan pengendalian di dalam organisasi (Djahir, 2014).

Sistem Informasi Akademik adalah Sistem yang memberikan layanan informasi yang berupa data dalam hal yang berhubungan dengan akademik. Dimana dalam hal ini pelayanan yang diberikan yaitu penyimpanan data untuk siswa baru, penentuan kelas, penentuan jadwal pelajaran, pembuatan jadwal mengajar, pembagian wali kelas, proses penilaian (Imelda \& Erik, M., 2014).

\subsection{End User Computing Satisfaction (EUCS)}

Pengukuran terhadap kepuasan telah mempunyai sejarah yang panjang dalam disiplin ilmu sistem informasi. Dalam lingkup end-user computing, sejumlah studi telah dilakukan untuk meng-capture keseluruhan evaluasi dimana pengguna akhir telah menganggap 
pengguna dari suatu sistem informasi (misalnya kepuasan) dan juga faktor-faktor yang membentuk kepuasan ini.

Model evaluasi EUCS ini dikembangkan oleh Doll \& Torkzadeh. Evaluasi dengan menggunakan model ini lebih menekankan kepuasan (satisfaction) pengguna akhir terhadap aspek teknologi, dengan menilai isi, keakuratan, format, waktu dan kemudahan penggunaan dari sistem. Model ini telah banyak di uji cobakan oleh peneliti lain untuk menguji reliabilitasnya dan hasilnya menunjukkan tidak ada perbedaan bermakna meskipun instrument ini diterjemahkan dalam bahasa yang berbeda.

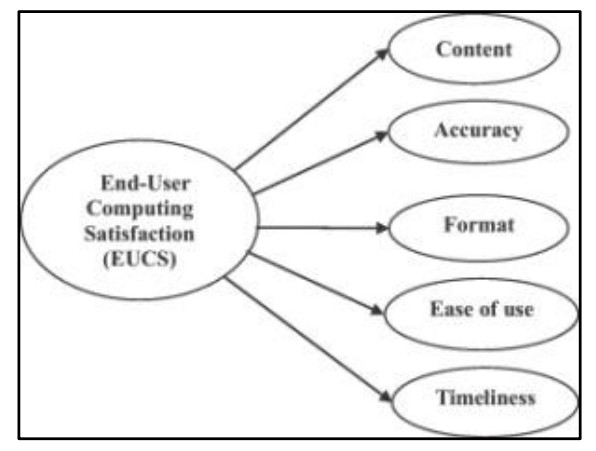

Gambar 1 EUCS Model

Berikut adalah penjelasan dari tiap dimensi yang diukur dengan model end user computing satisfaction menurut Doll \& Torkzadeh:

1. Dimensi Content. Dimensi content mengukur kepuasan pengguna ditinjau dari sisi isi dari suatu sistem. Isi dari sistem biasanya berupa fungsi dan modul yang dapat digunakan oleh pengguna sistem dan juga informasi yang dihasilkan oleh sistem.Dimensi content juga mengukur apakah sistem menghasilkan informasi yang sesuai dengan kebutuhan pengguna. Semakin lengkap modul dan informatif sistem maka tingkat kepuasan dari pengguna akan semakin tinggi.

2. Dimensi Accuracy. Dimensi accuracy mengukur kepuasan pengguna dari sisi keakuratan data ketika sistem menerima input kemudian mengolahnya menjadi informasi. Keakuratan sistem diukur dengan melihat seberapa sering sistem menghasilkan output yang salah ketika mengolah input dari pengguna, selain itu dapat dilihat pula seberapa sering terjadi error atau kesalahan dalam proses pengolahan data.

3. Dimensi Format. Dimensi format mengukur kepuasan pengguna dari sisi tampilan dan estetika dari antarmuka sistem, format dari laporan atau informasi yang dihasilkan oleh sistem apakah antarmuka dari sistem itu menarik dan apakah tampilan dari sistem memudahkan pengguna ketika menggunakan sistem sehingga secara tidak langsung dapat berpengaruh terhadap tingkat efektifitas dari pengguna.

4. Dimensi Ease of Use. Dimensi ease of use mengukur kepuasan pengguna dari sisi kemudahan pengguna atau user friendly dalam menggunakan sistem seperti proses memasukkan data, mengolah data dan mencari informasi yang dibutuhkan.Dimensi Timeliness. Dimensi timeliness mengukur kepuasan pengguna dari sisi ketepatan waktu sistem dalam menyajikan atau menyediakan data dan informasi yang dibutuhkan oleh pengguna. Sistem yang tepat waktu dapat dikategorikan sebagai sistem realtime, berarti setiap permintaan atau input yang dilakukan oleh pengguna akan langsung diproses dan output akan ditampilan secara cepat tanpa harus menunggu lama.

Penelitian ini bersifat deskriptif kuantitatif dengan menjabarkan kepuasan pengguna dalam penerapan simak online pada Universitas Islam Negeri Raden Fatah Palembang menggunakan metode analisis kepuasan pengguna akhir dengan EUCS. EUCS memiliki lima (5) dimensi yaitu content, accuracy, format, ease of use, dan timeliness. Penelitian kuantitatif dengan teknik pengumpulan data yang utama adalah kuesioner. 


\subsection{Populasi}

Populasi dari penelitian ini adalah semua pengguna akhir dari simak online yang terdiri dari mahasiswa/i dan dosen (jenjang pendidikan s1, s2, s3) Universitas Islam Negeri Raden Fatah Palembang dengan jumlah mahasiswa/i 14658 mahasiswa/i dan dosen sebanyak 435 dosen dengan total populasi keseluruhan 15093 pengguna.

\subsection{Sample}

Penelitian ini yang mengambil sampel mahasiswa/i dan dosen dengan jumlah populasi sebanyak 15093 populasi yang terdiri dari 14.658 mahasiswa/i dan 435 dosen. Dengan populasi berjumlah 15093 dan menggunakan e= 5\%, maka jumlah sampel yang digunakan adalah:

$\mathrm{S}=\mathrm{N} / \mathrm{N} \cdot \mathrm{d} 2+1$

$\mathrm{S}=15093 / 15093 \times 0,052+1$

$\mathrm{S}=15093 / 38,73$

$\mathrm{S}=389,672=390$

Berdasarkan perhitungan menggunakan rumus slovin serta berdasarkan metode EUCS sampel didapat sebanyak 390 responden yang meliputi pengguna akhir dari simak online Universitas Islam Negeri Raden Fatah Palembang.

\subsection{Operasional dan Skala Pengukuran Variabel}

Penelitian ini memiliki variabel tunggal yang terdiri dari:

1. Content

2. Accuracy

3. Format

4. Ease of use

5. Timeliness

Secara lengkap, operasional variabel-variabel penelitian dapat dilihat pada Tabel 1 berikut ini:

Tabel 1. Variabel Pada Penelitian

\begin{tabular}{|c|c|c|c|}
\hline Var & Dimensi & Indikator & Ukuran \\
\hline \multirow{4}{*}{$\begin{array}{c}\text { Isi } \\
\text { (content) }\end{array}$} & Informasi & $\begin{array}{l}\text { Informasi-informasi } \\
\text { yang tersedia di simak } \\
\text { online berhubungan dan } \\
\text { sesuai dengan } \\
\text { kebutuhan }\end{array}$ & $\begin{array}{l}\text { Tingkat } \\
\text { Kesesuaian }\end{array}$ \\
\hline & Kelengkapan & $\begin{array}{l}\text { Semua informasi yang } \\
\text { dibutuhkan tersedia di } \\
\text { simak online }\end{array}$ & $\begin{array}{l}\text { Tingkat } \\
\text { Ketersediaan }\end{array}$ \\
\hline & Manfaat & $\begin{array}{lr}\text { Informasi yang } & \text { tersedia } \\
\text { di simak online } \\
\text { mendukung } & \text { dan } \\
\text { bermanfaat } & \end{array}$ & Tingkat manfaat \\
\hline & Output & $\begin{array}{lr}\text { Simak } & \text { online } \\
\text { menyediakan } & \text { laporan- } \\
\text { laporan } & \end{array}$ & $\begin{array}{l}\text { Tingkat } \\
\text { kebenaran }\end{array}$ \\
\hline & Teliti & Informasi sesuai dengan & Tingkat \\
\hline $\begin{array}{r}\text { Keakuratan } \\
\text { (accuracy) }\end{array}$ & Akurat & $\begin{array}{l}\text { hak akses pengguna } \\
\text { yang menggunakan } \\
\text { Informasi yang tersedia } \\
\text { di website bebas dari } \\
\text { kesalahan }\end{array}$ & $\begin{array}{l}\text { Ketelitian } \\
\text { Tingkat } \\
\text { Kebenaran }\end{array}$ \\
\hline
\end{tabular}




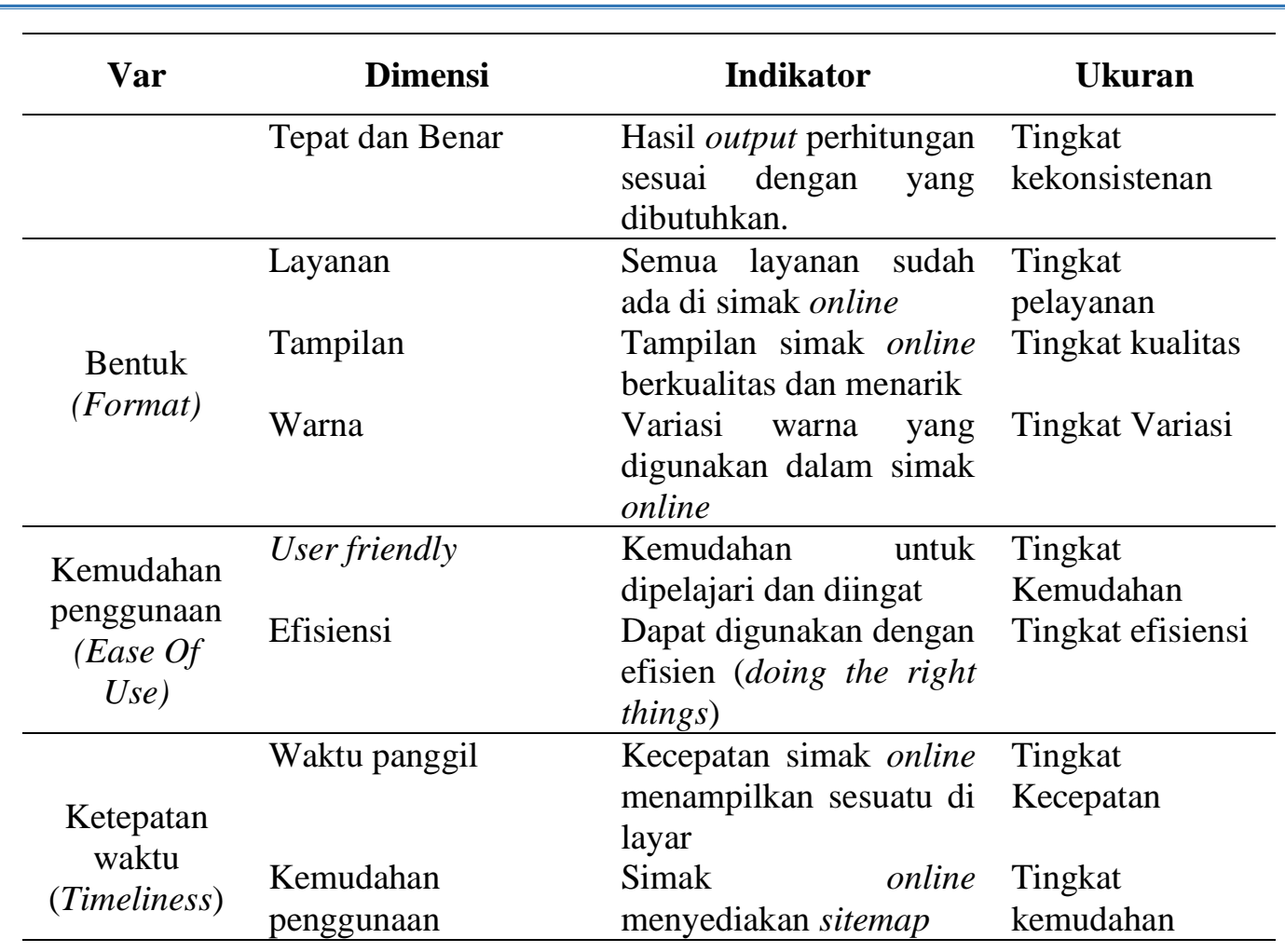

\subsection{Teknik analisis data}

Teknik pengumpulan data dilakukan dengan menggunakan kuesioner, maka kesungguhan responden dalam menjawab pernyataan-pernyataan merupakan hal yang sangat penting dalam penelitian. Keabsahan atau kesahihan suatu hasil penelitian sosial sangat ditentukan olehalat ukut yang digunakan. Apabila alat ukur yang dipakai tidak valid dan atau tidak dapat dipercaya, maka hasil penelitian yang dilakukan tidak akan menggambarkan keadaan yang sesungguhnya. Dalam mengatasi hal tersebut diperlukan dua macam pengujian yaitu validitas (test of validity) dan uji keandalan (test of reliability) untuk menguji kesungguhan jawaban responden.

Instrumen yang digunakan adalah kuesionertipe pilihan dengan jawaban yang tersedia berupa angka-angka interval dari 1 sampai 5 . Kuesionertersebut akan di uji dengan uji validitas dan reliabilitas yang dilakukan dengan aplikasi komputer SPSS (Statistical Product of Social Sciencies) for windows versi 22.

\subsubsection{Uji validitas}

Uji validitas dilakukan dengan menggunakan teknik korelasi Product Moment dengan mengkorelasikan masing-masing pertanyaan dengan jumlah skor untuk masing-masing variabel. Angka korelasi yang diperoleh secara statistik harus dibandingkan dengan angka kritik table korelasi nilai $\mathrm{r}$ dengan taraf signifikan $95 \%$.

Dalam penelitian ini penulis untuk melakukan uji validitas disebarkan sebanyak 60 kuesioner kepada pengguna akhir simak online Universitas Islam Negeri Raden Fatah Palembang.

Tabel 2 Hasil Uji Validitas

\begin{tabular}{cccccc}
\hline No & variabel & Pernytaan & $\mathrm{r}_{\text {hitung }}$ & $\mathrm{r}_{\text {tabel }}$ & Ket \\
\hline 1 & Content & C1 & 0,874 & 0,254 & Valid \\
& & C2 & 0,804 & 0,254 & Valid \\
& & C3 & 0,884 & 0,254 & Valid \\
& & C4 & 0,764 & 0,254 & Valid \\
\hline
\end{tabular}


34 | JUSIFO (Jurnal Sistem Informasi), p-ISSN: 2460-092X, e-ISSN: 2623-1662

\begin{tabular}{cccccc}
\hline \hline No & variabel & Pernytaan & r $_{\text {hitung }}$ & rtabel & Ket \\
\hline 2 & Accuracy & A1 & 0,872 & 0,254 & Valid \\
& & A2 & 0,829 & 0,254 & Valid \\
& & A3 & 0,859 & 0,254 & Valid \\
& & A4 & 0,775 & 0,254 & Valid \\
\hline 3 & Format & F1 & 0,775 & 0,254 & Valid \\
& & F2 & 0,755 & 0,254 & Valid \\
& & F3 & 0,731 & 0,254 & Valid \\
& & F4 & 0,794 & 0,254 & Valid \\
\hline 4 & Ease Of Use & E1 & 0,783 & 0,254 & Valid \\
& & E2 & 0,772 & 0,254 & Valid \\
& & E3 & 0,839 & 0,254 & Valid \\
& & E4 & 0,826 & 0,254 & Valid \\
\hline 5 & Timeliness & T1 & 0,773 & 0,254 & Valid \\
& & T2 & 0,825 & 0,254 & Valid \\
& & T3 & 0,826 & 0,254 & Valid \\
& & T4 & 0,772 & 0,254 & Valid \\
\hline
\end{tabular}

Berdasarkan Tabel $3.2 \mathrm{r}_{\text {hitung }}$ dengan taraf signifikasi 0,254 maka instrumen penelitian ini dinyatakan valid.

\subsubsection{Uji realibilitas}

Setelah dilakukan uji validitas atas pernyataan yang digunakan dalam penelitian ini, selanjutnya dilakukan uji reliabilitas. Uji reliabilitas bertujuan untuk mengetahui apakah alat pengumpul data pada dasarnya menunjukan tingkat ketepatan, keakuratan, kestabilan atau konsistensi alat tersebut dalam mengungkapkan gejala tertentu dari sekelompok inividu, walaupun dilakukan pada waktu yang berbeda. Uji keandalan dilakukan terhadap pernyataan yang sudah valid.Pengujian ini dilakukan dengan menggunakan teknik Cronbach's Alpha, karena nilai jawaban terdiri dari rentangan nilai dengan koefisien alpha harus lebih besar. Dapat dilihat pada Tabel 3 berikut ini:

Tabel 3 Hasil Cronbach's Alpha

\begin{tabular}{clccl}
\hline No. & Variabel & $\begin{array}{c}\text { Cronbach's } \\
\text { Alpha }\end{array}$ & N of Items & Ket. \\
\hline 1 & Content & 0,823 & 20 & Baik \\
2 & Accuracy & 0,824 & 20 & Baik \\
3 & Format & 0,802 & 20 & Baik \\
4 & Ease Of Use & 0,817 & 20 & Baik \\
5 & Timeliness & 0,814 & 20 & Baik \\
\hline
\end{tabular}

Dari instrumen soal yang dianalisis dengan bantuan komputer program SPSS for windows versi 22, maka hasil uji reliabilitas diperoleh nilai Cronbach's Alpha 0,6 nilai terletak pada 0,824 - 0,814 sehingga dapat disimpulkan nilai reliabilitas tinggi.

\section{HASIL DAN PEMBAHASAN}

Model ini terdapat lima (5) variabel yang dikaji dan dianalisis, variabel tersebut adalah variabel Content, Accuracy, Format, Ease of Use, dan Timeliness.

\subsection{Variabel Content $\left(\mathrm{X}_{1}\right)$}

Berdasarkan hasil dari pengolahan data yang bersumber dari kuesioner, maka hasil untuk variabel content dapat dilihat seperti pada Tabel di bawah ini: 
Pada Tabel 4, hasil yang didapat responden menjawab sangat setuju $16,79 \%$, responden menjawab setuju 50,44\%, responden menjawab cukup setuju $27,88 \%$, responden menjawab tidak setuju $4,55 \%$, responden menjawab sangat tidak setuju $0,32 \%$, dapat dilihat pada diagram chart di bawah ini:

Tabel 4 Hasil Variabel Content

\begin{tabular}{clccc}
\hline No & \multicolumn{1}{c}{ Jawaban } & Skala Likert & Frekuensi & Persentase (\%) \\
\hline 1 & Sangat Setuju & 5 & 262 & 16,79 \\
2 & Setuju & 4 & 787 & 50,44 \\
3 & Cukup Setuju & 3 & 435 & 27,88 \\
4 & Tidak Setuju & 2 & 71 & 4,55 \\
5 & Sangat Tidak Setuju & 1 & 5 & 0,32 \\
\hline \multicolumn{2}{r}{ Total } & & 1560 & 100 \\
\hline
\end{tabular}

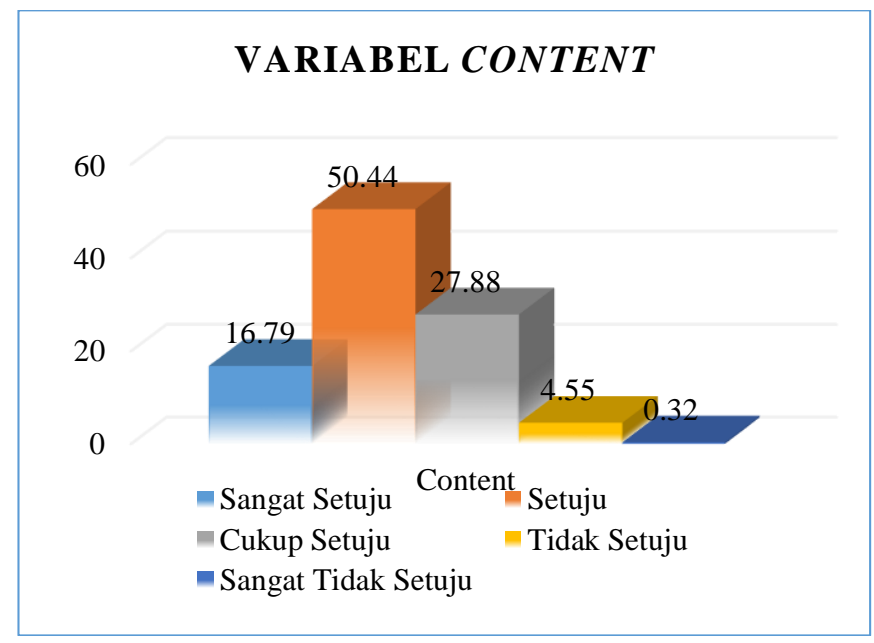

Gambar 2. Diagram Chart Variabel Content

\subsection{Variabel Accuracy $\left(\mathrm{X}_{2}\right)$}

Tabel distribusi frekuensi variabel accuracy berdasarkan hasil pengumpulan kuesioner yang sudah diolah, dapat dilihat pada Tabel 5 berikut ini:

Tabel 5. Hasil Variabel Accuracy

\begin{tabular}{clccc}
\hline No. & \multicolumn{1}{c}{ Jawaban } & Skala Likert & Frekuensi & Persentase (\%) \\
\hline 1 & Sangat Setuju & 5 & 230 & 14,74 \\
2 & Setuju & 4 & 729 & 46,73 \\
3 & Cukup Setuju & 3 & 517 & 33,14 \\
4 & Tidak Setuju & 2 & 80 & 5,12 \\
5 & Sangat Tidak Setuju & 1 & 4 & 0,25 \\
\hline \multicolumn{2}{c}{ Total } & & $\mathbf{1 5 6 0}$ & $\mathbf{1 0 0}$
\end{tabular}

Dari Tabel 5 hasil yang didapat responden menjawab sangat setuju 14,74\%. Menjawab cukup setuju $33,14 \%$, responden menjawab tidak setuju 5,12\%, responden menjawab sangat tidak setuju $0,25 \%$, dapat dilihat pada diagram chart berikut ini: 


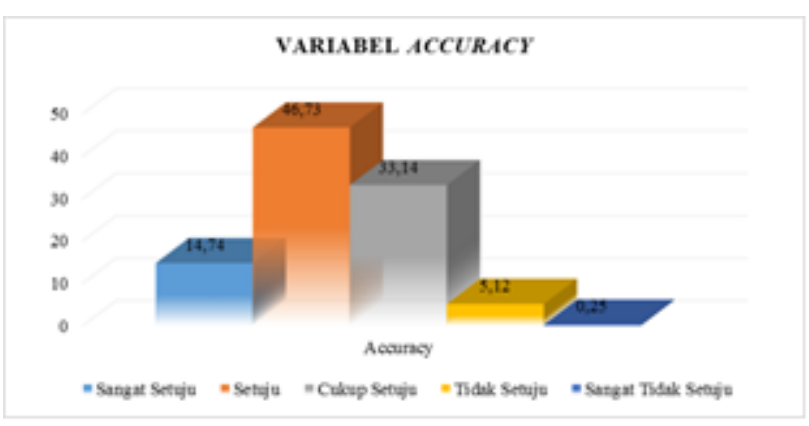

Gambar 3 Diagram Chart Variabel Accuracy

\subsection{Variabel Format $\left(\mathrm{X}_{3}\right)$}

Berikut ini adalah tabel distribusi frekuensi variabel format berdasarkan hasil pengumpulan kuesioner yang sudah diolah, dapat dilihat pada Tabel 6 berikut ini:

Tabel 6 Distribusi Variabel Format $\left(\mathbf{X}_{3}\right)$

\begin{tabular}{clccc}
\hline No. & \multicolumn{1}{c}{ Jawaban } & $\begin{array}{c}\text { Skala } \\
\text { Likert }\end{array}$ & Frekuensi & Persentase (\%) \\
\hline 1 & Sangat Setuju & 5 & 169 & 10,83 \\
2 & Setuju & 4 & 641 & 41,08 \\
3 & Cukup Setuju & 3 & 581 & 37,24 \\
4 & Tidak Setuju & 2 & 159 & 10,19 \\
5 & Sangat Tidak Setuju & 1 & 10 & 0,64 \\
\hline \multicolumn{2}{r}{ Total } & & $\mathbf{1 5 6 0}$ & $\mathbf{1 0 0}$ \\
\hline
\end{tabular}

Tabel 6 menjelaskan hasil yang didapat responden menjawab sangat setuju 10,83\%, responden menjawab setuju $41,08 \%$, responden menjawab cukup setuju $37,24 \%$, responden menjawab tidak setuju $10,19 \%$, responden menjawab sangat tidak setuju $0,64 \%$, dapat dilihat pada diagram chart berikut ini:

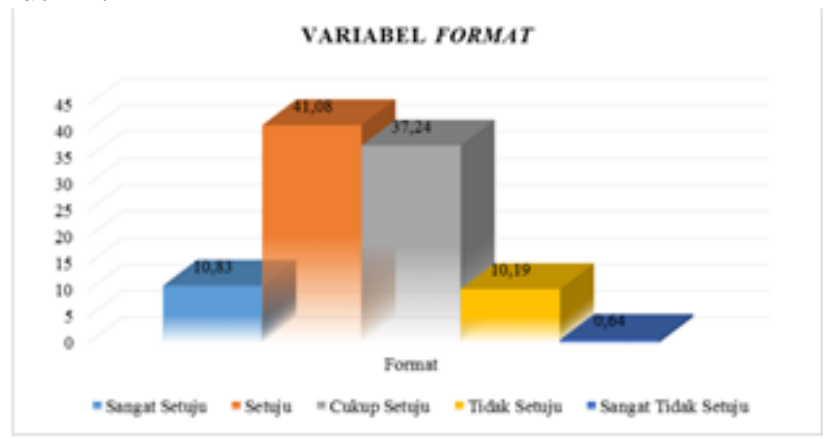

Gambar 4. Diagram Chart Variabel Format

\subsection{Variabel Ease of Use (X4)}

Berikut ini adalah tabel distribusi frekuensi variabel Ease of Use berdasarkan hasil pengumpulan kuesioner yang sudah diolah, dapat dilihat pada Tabel 7 berikut ini:

Tabel 7. Distribusi Variabel Ease of Use 


\begin{tabular}{clccc}
\hline No. & \multicolumn{1}{c}{ Jawaban } & Skala Likert & Frekuensi & Persentase (\%) \\
\hline 1 & Sangat Setuju & 5 & 204 & 13,07 \\
2 & Setuju & 4 & 693 & 44,42 \\
3 & Cukup Setuju & 3 & 513 & 32,88 \\
4 & Tidak Setuju & 2 & 141 & 9,03 \\
5 & Sangat Tidak Setuju & 1 & 9 & 0,57 \\
\hline \multicolumn{2}{r}{ Total } & & $\mathbf{1 5 6 0}$ & $\mathbf{1 0 0}$
\end{tabular}

Tabel 7 menunjukkan hasil yang didapat responden menjawab sangat setuju 13,07\%, responden menjawab setuju $44,42 \%$, responden menjawab cukup setuju $32,88 \%$, responden menjawab tidak setuju $9,03 \%$, responden menjawab sangat tidak setuju $0,57 \%$, dapat dilihat pada diagram chart berikut ini:

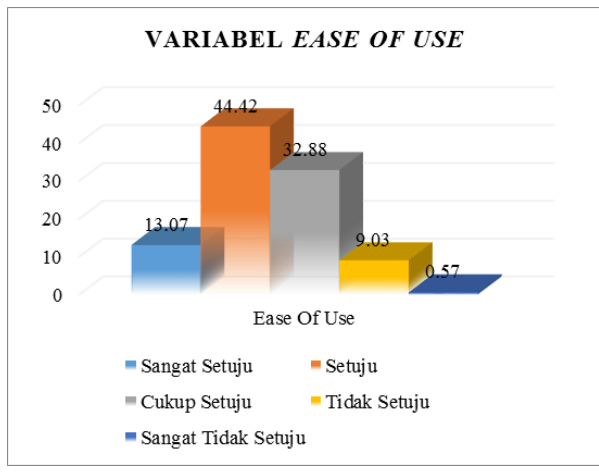

\section{Gambar 5. Diagram Chart Variabel Ease of Use}

\subsection{Variabel Timeliness $\left(\mathrm{X}_{5}\right)$}

Berikut ini adalah tabel distribusi frekuensi variabel timeliness berdasarkan hasil pengumpulan kuesioner yang sudah diolah, dapat dilihat pada Tabel 8 berikut ini:

Tabel 8. Distribusi Variabel Timelines

\begin{tabular}{ccccc}
\hline No. & Jawaban & Skala Likert & Frekuensi & Persentase (\%) \\
\hline 1 & Sangat Setuju & 5 & 168 & 10,76 \\
2 & Setuju & 4 & 571 & 36,60 \\
3 & Cukup Setuju & 3 & 579 & 37,11 \\
4 & Tidak Setuju & 2 & 213 & 13,65 \\
5 & Sangat Tidak Setuju & 1 & 29 & 1,85 \\
\hline Total & & $\mathbf{1 5 6 0}$ & $\mathbf{1 0 0}$ \\
\hline
\end{tabular}

Tabel 8 menunjukkan hasil yang didapat responden menjawab sangat setuju 10,76\%, responden menjawab setuju $36,60 \%$, responden menjawab cukup setuju $37,11 \%$, responden menjawab tidak setuju $13,65 \%$, responden menjawab sangat tidak setuju 1,85\%, dapatdilihat pada diagram chart berikut ini:

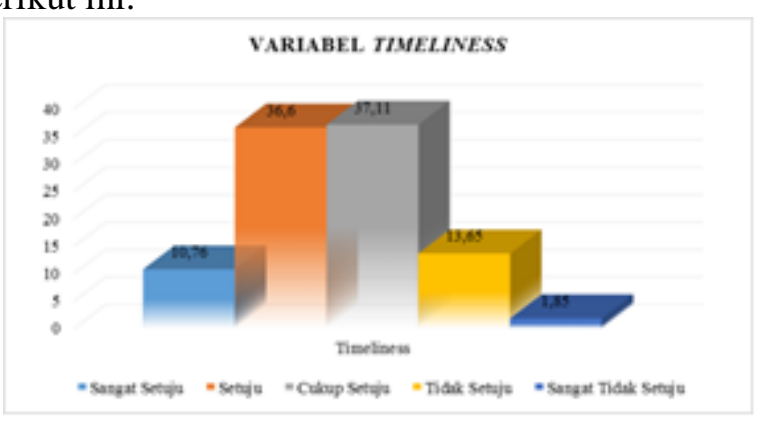

Gambar 6. Diagram Chart Variabel Timelines 
Secara keseluruhan dilihat dari hasil perhitungan kuesioner (terlampir) variabel content, accuracy, format, ease of use, timeliness, dapat dilihat pada Tabel 9.

Tabel 9. Hasil Perhitungan Skala Likert

\begin{tabular}{clc}
\hline No. & \multicolumn{1}{c}{ Variabel EUCS } & Hasil \\
\hline 1 & Content & 4 (Puas) \\
2 & Accuracy & 4 (Puas) \\
3 & Format & 4 (Puas) \\
4 & Ease Of Use & 4 (Puas) \\
5 & Timeliness & 3 (Cukup Puas) \\
\hline
\end{tabular}

Berdasarkan pada Tabel 9 terlihat bahwa responden sudah merasa puas dalam penerapan simak online di Universitas Islam Negeri Raden Fatah Palembang, yaitu: rata-rata berada pada rentang nilai 4 dalam sisi content berada pada rentang nilai 4 dinyatakan responden merasa puas, dalam sisi accuracy berada pada rentang nilai 4 dinyatakan responden merasa puas, dalam sisi format berada pada rentang nilai 4 dinyatakan responden merasa puas, dalam sisi ease of use berada pada rentang nilai 4 dinyatakan responden merasa puas.

Demikian juga pada sisi timeliness berada pada rentang nilai 3 dinyatakan responden cukup puas, dapat dilihat pada diagram chart berikut ini:

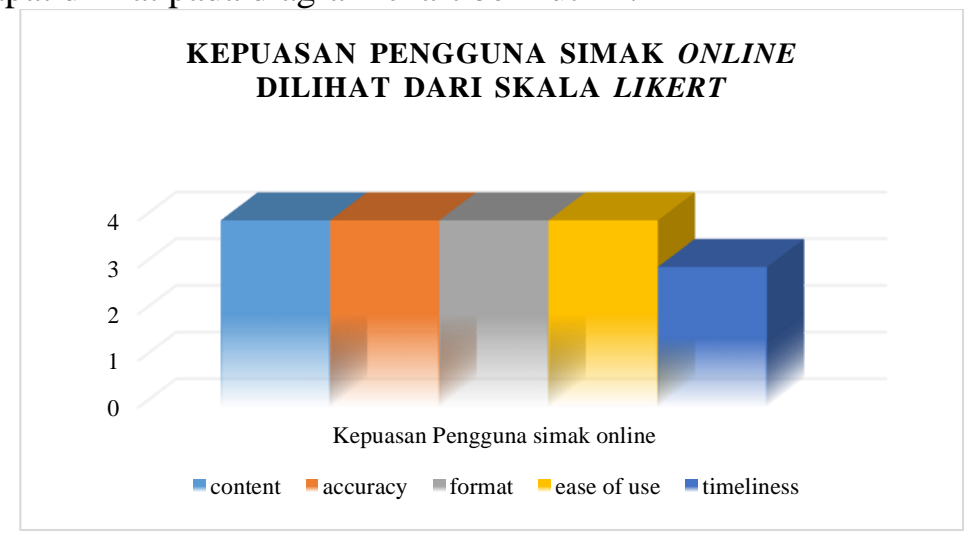

\section{Gambar 7. Diagram Chart Kepuasan Dari Skala Likert}

\section{KESIMPULAN}

Berdasarkan penelitian yang telah dilakukan maka dalam penelitian ini diambil kesimpulan:

1. Kepuasan pengguna penerapan simak online di Universitas Islam Negeri Raden Fatah Palembang pengguna akhir sudah merasa puas dalam penerapan simak online. Berdasarkan hasil analisis menggunakan EUCS dan skala likert, pengguna simak online pada sisi variabel content, accuracy, format, ease of use berada pada angka 4 yaitu puas dan pada sisi variabel timeliness berada pada angka 3 yaitu cukup puas.

2. Persentase tingkat kepuasan pengguna simak online sebesar $13 \%$ merasa sangat puas, $44 \%$ merasa puas, $34 \%$ merasa cukup puas, $9 \%$ merasa tidak puas, $1 \%$ merasa sangat tidak puas.

\section{DAFTAR RUJUKAN}

Djahir, Y. (2014). Sistem Informasi Manajemen. Yogyakarta: Deepublish. 
Doll, W. J., Xia, W., \& Torkzadeh, G. (1994). A Confirmatory Factor Analysis of the EndUser Computing Satisfaction Instrument. MIS Quarterly, 453-461.

Imelda \& Erik, M. (2014). Perancangan Sistem Informasi Akademik Pada Sekolah Dasar Negeri Sukajadi 9 Bandung. Jurnal Teknologi dan Informasi UNIKOM, 47-48.

Supranto, J. (2011). Pengukuran Tingkat Kepuasan Pelanggan Untuk Menaikkan Pangsa. Jakarta: Rineka Cipta.

Tjiptono, F. \& Chandra, G. . (2016). Service, Quality, dan Satisfaction. Yogyakarta: Andi. 
40 | JUSIFO (Jurnal Sistem Informasi), p-ISSN: 2460-092X, e-ISSN: 2623-1662

Volume 3, Nomor 1, Juni 2017 